\title{
MARXISM, SARCASM, ETHNOGRAPHY: GEOGRAPHICAL FIELDNOTES FROM SOUTH INDIA
}

\author{
Sharad Chari \\ Department of History and Department of Anthropology, \\ University of Michigan, Ann Arbor, USA
}

\begin{abstract}
This paper addresses questions of ethnography in geographic fieldwork through research conducted on globalisation and work in Tiruppur, an industrial boomtown in South India. During the last two decades of the twentieth century, Tiruppur town in western Tamilnad State became India's centrepiece in the export of garments made of knitted cloth. This industrial boom has been organised through networks of small firms integrated through intricate subcontracting arrangements controlled by local capital of Gounders from modest agrarian and working-class origins. In effect, the whole town works like a decentralised factory for the global economy, but with local capital of peasant-worker origins at the helm. My research explores the historical geographic trajectories linking agrarian and industrial work, and the ways in which these histories are used in the present. In these uses of the past in remaking self and place, I interrogate the self-presentations of Tiruppur's entrepreneurs, as these "self-made men" hinge their retrospective narratives of class mobility and industrial success on their propensity to "toil". This paper explores questions of ethnographic method emerging from a political-economic context in which globalisation has worked by turning "toil" into capital.
\end{abstract}

Keywords: ethnography, fieldwork, globalisation, capital, gender, subaltern

\section{INTRODUCTION}

I work at the University of Michigan, which lost its Geography Department in the downsizing of universities in the United States during the 1980s. Work in the Anthropology and History Departments has afforded me a keen sense of how geography is viewed outside the discipline. To help me feel at home, a colleague in anthropology led me to Franz Boas' 1887 essay, "The Study of Geography", an impassioned defence of geography as a discipline. ${ }^{1}$ Boas differentiates "affective" from "aesthetic" impulses in intellectual work, the first, drawn to phenomena-in-themselves, the second, to explanation as abstraction, as the instantiation of general laws. Geography's strength rests on what Boas (1966:647) sees as its affective impulse: "the desire to understand the phenomena and history of a country or of the whole earth, the home of mankind". To be sure, this statement belies a will-to-power common to anthropology and geography in their complex links to empire and colonialism. Yet, for a postcolonial human geography vigilant of reducing complex phenomena to explanations abstracted from hyperreal Eurocentric histories, this affective 
impulse deserves careful rethinking. The alternative may indeed be Boas' (1966:640) fatalism about the future of geography: "geography must either be maintained in its full extent or it must be given up altogether". Given that most of the analytical questions geographers ask share vocabularies with other disciplines, spatial prefixes aside, I would like to suggest that an affective impulse attentive to the politics of ethnography is central to human geographic fieldwork. Indeed, if one is to use this affective impulse to ascertain nascent and multiple "structures of feeling" in Raymond Williams'(1977:132) sense - "not feeling against thought, but thought as felt and feeling as thought: practical consciousness of a present kind, in a living and interrelating continuity" - then ethnography is surely central to Marxist geography. This reflection on fieldwork in South India offers a set of challenges for ethnography in postcolonial geography.

My research, conducted between 1996 and 1998 , centres on dramatic developments in the South Indian town of Tiruppur, in the Coimbatore District of western Tamilnad State. During the last two decades of the twentieth century, Tiruppur became India's centrepiece in the export of garments made of knitted cloth. Between 1986 and 1997, Tiruppur's export earnings skyrocketed from US\$25 million to US\$636 million, the number of garments exported increased more than ninefold, and production shifted from basic T-shirts to diversified exports of fashion garments. This industrial boom has been organised through networks of small firms integrated through intricate subcontracting arrangements controlled by local capital of Gounders - the dominant agrarian caste in Coimbatore - from modest agrarian and working-class origins. In effect, the whole town works like a decentralised factory for the global economy, but with local capital of peasant-worker origins at the helm. What is more, these "self-made men" hinge their retrospective narratives of class mobility and industrial success on their propensity to "toil": the word ulaippu is distinct from the conventional Tamil word for work. My research asks how Gounder peasant-workers remade the social and spatial dynamics of work through their propensity to toil, thereby making Tiruppur an industrial powerhouse. The central concern of this project is with the regional geographies, cultural histories and spatial practices of work that have enabled certain subaltern men to accumulate capital in provincial India (Chari, 1998; 2000; forthcoming). Elsewhere (Chari, forthcoming), I explicate my larger argument through the intertwined remaking of place, spatial relations and identities, with attention to the permeability and relational construction of each. In this piece, I concentrate primarily on questions of ethnographic method emerging from this research project.

This paper uses Tiruppur's local spacetimes of work, gender and global production to explore a series of ethnographic questions arising from the tension between Marxist geography and fieldwork in the postcolony. I begin by drawing some insights from Spivak's (1988) felicitous problematic: "Can the subaltern speak?", which questions intellectual approaches that constitute the investigator as sovereign subject who must necessarily be complicit with the constitution of the other. Embedded in the intellectual's move to render investigation transparent, Spivak (1988:275) identifies a conflation of two meanings of representation: "“speaking-for' as in politics, and 're-presentation' as in art or philosophy". The subaltern cannot speak precisely because in the process of "speakingfor", the subaltern is re-presented through hyperreal categories that conceal their cultural histories and politics of comparison. Alternatively, "speaking-alongside" the subaltern permits singularity without concealing processes of subjection by nonrepresentative power relations. Returning to this problematic a decade later, Spivak (2001:120) refuses to "occlude the traces of the irreducibly autobiographical in cultural speculation", whereby her own stance might be read for its apparent politics of identity. In 
reframing the problem of speaking-for, Spivak (2001:124) thinks through an Indic episteme of $d v a i t a$ or dualism as a structure of feeling that allows the possibility of the "invagination" through which the radical otherness of supernatural beings is enfolded in the natural. Bracketing this as a creative elaboration on Derridean and Indic registers, I want to take Spivak's argument off-course by questioning the way in which emergent structures of feeling mediate the political aspect of the dual problem of representation. In other words, while maintaining Spivak's postcolonial feminist stance of "standing alongside" the subaltern, I want to insist that the investigator must not preclude the possibility of changing social conditions that can radically transform the grounds for speaking-for, even opening new avenues for subaltern self-presentation and action.

In approaching a context of tremendous, though exclusionary, class mobility, and without writing as if the present were the only possible outcome, I have been forced to see Gounder narratives of self-making as enabled by broader social transformations. I view these narratives as tenuous reflections that do not simply impart in didactic fashion an ideology of "toil", but instead reveal the many sleights of hand required to present histories of class mobility as cohesion. In other words, Gounder self-presentations as "self-made men" cannot be divorced from the arduous histories of transition from agrarian to industrial work and the traces of agrarian work practices that have been remembered, renovated and reused in the quest for political-economic security. Hence, my use of the word "subaltern" is not as a hyperreal category that combines sociological universalisms of caste, class and gender, as this would be at odds with Spivak's injunction. The subaltern is defined through subordination in relations of power and knowledge, but subaltern knowledges, such as Gounder narratives of self-making, might be used to capture, in exclusionary ways, the opportunities afforded by capitalist modernity.
Hence, the class mobility of Gounders opens up a terrain of possible ways of interrogating why subalterns appear differently through the practice of investigating divergent social locations and cultural-historic legacies. I ask what it means for investigation to find working-class people speaking with elements of the dominant ideology of "Gounder toil" while also illuminating its conditions of possibility. I also ask how ethnographers might consider the multifunctionality of language, as signs refer not just to the real-time here and now, but also to shared historical, cultural and structural preconditions for present interactions. As I will argue, when my working-class friends mocked my own presumptions about the hold of dominant ideology, twirling their imaginary moustaches as nascent self-made men might do, their sarcasm was more important than their words. Attention to the subtle movements of affect, of stance, tone and bodily comportment, are as important to the workings of power and knowledge, and to the illumination of daily struggles over the course of social change. Attention to structures of feeling in everyday practice requires better analytical tools, for which I argue that developments in linguistic anthropology are particularly useful for geographical fieldwork. This paper is a preliminary step in this direction.

\section{ETHNOGRAPHIC “OTHERS”AND PRESUMPTIONS OF SOLIDARITY}

Spivak's interventions, among others, have decisively challenged the presumption of "recovery" of subaltern histories, practices and forms of consciousness. There are multiple ways of charting the critique of social history and "salvage ethnography", but that is not the point of this paper. What is important here is the interpretation of ethnography as a process of alienation, through which, for instance, ethnographers poach on workingclass narrators for very different ends: like getting a job or getting tenure. I turn to the scholarship of the historian Carolyn Steedman for her very useful ways of unpacking modes 
of ethnographic engagement and the politics therein. Steedman (2000a) writes on the ways in which nineteenth-century British socialist feminists would prospect for working-class stories in the dark alleys of the London underclass, but at some point would substitute solidarity with fear, reproducing bourgeois representations of these zones as dens of vice, places where prostitution, drugs, homosexuality and criminality were rampant. These spatial imaginaries were of course misrepresentations, but their significance lay more importantly in remaking the bourgeois respectability of these elite socialist feminists. On its own, this account would suggest the most pessimistic affirmation of Spivak's question: that the narratives of the poor are bound to be used for alternate ends and, indeed, the claim to represent "them" is mere folly at best, and a form of class domination at worst.

On the other hand, Steedman (2000b) writes also of the very different trajectory taken by Eleanor Marx, who lost herself in London's working-class neighbourhoods and was reviled by contemporary elites as having become a whore and drug addict herself. Rather than protect her bourgeois respectability, Steedman implies that Marx managed to circumvent a process of othering by building solidarity with her subjects. What is more, Marx was deliciously sarcastic in her conversations with patrician Londoners. I want to turn to this sarcasm, not just because her father, Karl, was just as sarcastic in lambasting traditional political economy, but also because it seems that the Marxs were also critical of taking working-class consciousness at face value, while making clear where their political solidarities lay. The politics of ethnography were never clear-cut, nor were their claims to represent transparent.

If critical ethnography attempts to understand actual processes of power and inequality without treating these processes as natural or inevitable, the question is: how does the ethnographic encounter capture the present as brittle and contradictory? Sarcasm, for Eleanor Marx, was one way for preventing a slide into modes of sympathy that occludes difference through universalism, thereby sealing off possibilities of solidarity around goals of social transformation. Marx's sarcasm could be seen as more than a refusal to speak for working class subjects, as it openly marks its distance from traditional modes of elitesocialist appropriation of subaltern knowledge. Implicitly, sarcasm stakes political claims without appealing to speaking for the subaltern.

I want to suggest that sarcasm can also be used as an analytical tool for situating people's expressions of dissatisfaction in experienced discrepancies between the expected and the actual. For instance, capitalist development might be expected, according to its liberal proponents, to provide for the consumption needs of working people through deepening markets, while it might actually erode livelihoods in a variety of ways. In Chari (forthcoming), I argue that Third World agrarian traditions in Marxism have been particularly vigilant in charting how capitalism's anarchic spatio-temporal movements allow particular capital to use noncapitalist distinctions and forms of exclusion to squeeze labour beyond the expectations of the ideal of "free labour" contracts. In this paper, I draw on ethnographic fieldnotes to show how ethnographies of place might take the interrelations of language and political economy more seriously to capture discrepancies in real geographies rather than using qualitative data in narrowly functionalist ways. I want to suggest that neither Eleanor nor Karl Marx's sarcasm may have been solely for rhetorical effect or even just to lambaste traditional intellectuals, but also meant to challenge the working-class audiences they sought to speak with. As an affective stance, sarcasm of this type is not condescension but a critique of subjective knowledge as being sufficient for understanding the nature of modern forms of power and exploitation. 
In unpacking the ways in which Tiruppur has become a global powerhouse through a fraction of capital that has emerged from modest, working-class/caste origins, I had to contend very quickly not only with actual trajectories of class mobility but also with an ideology of self-made men as it stood in tension with alternate structures of feeling. On one occasion, on my return from a midresearch trip to the United States, I met a group of working-class friends at a local tea stall near the railway station. They jokingly berated me for not bringing them back export orders so that they could all become "big capitalists", at which point they all on cue twirled their large, imaginary moustaches like self-made men. This sarcasm was a reminder of the limits of a hegemonic narrative that sought to blur specific meanings of Gounder masculinity, class mobility and exploitation through the myth that the market rewards entrepreneurial individualism. I now turn to the ways in which I began to understand through narratives the relations between changing identities, spatial relations and the politics of place.

\section{FINDING "SELF-MADE MEN" THROUGH MULTIPLE GENRES OF NARRATION}

We came to work from a 10 to 20 -mile radius. All those who have succeeded in Tiruppur have come from more than $15 \mathrm{~km}$. If you look at older families from Tiruppur, with grandparents, reputations, comfortable homes... these people have not succeeded... because they would keep looking at their watch to see when five o'clock came. When it was five, the town worker would take his shirt, cover his head and leave. He'd go off and talk about MGR and Shivaji [both film icons] or Lenin and Stalin, he'd talk about film and politics all night long; then he'd come slowly in the morning, never before eight. The rural worker would never talk back to the owner. We would do all sorts of things for the owner: stand by the threshold, get water and tea. The town worker would say: "no, that's not my job" and leave. To workers who listened, the owner would give any work... he'd get O.C. [on company] ${ }^{2}$ work from them. I worked, toiled; Gounders will toil. No other caste would stand against this. We suffered more, toiled more (Tommy Kandasamy, interview, 11 June 1997).

Most owners here aren't big owners. Most still go to work in their companies. If you tried to find rich owners, you won't find a majority in banian [undershirt] companies. A banian company cannot run if labour and owner are on opposite sides, and if they don't respect each other. Both have to work together in order for a company to grow. These Gounder farmers are used to working the Vanna, Nasuva, Cakkilian [agrarian service castes and Dalits $]^{3}$ by scolding them and extracting their labour. In the same way, in banian companies the owners have to scold the workers and extract work from them. Owner and worker have to combine, they can't be on different levels. That's why rich owners couldn't stand in this industry. You didn't need to enter with large capital. You just had to work, and manage work and the office and quality all at once. Big men couldn't stand. Only small people from modest backgrounds have succeeded (New Saturn Nalasamy Gounder, interview, 12 March 1997.

During my first year of fieldwork in Tiruppur, in which I collected life histories and extended narratives from a wide variety of residents in the town and its rural environs, I puzzled over narratives such as these. I found at the end of this first research trip that I could not rest until I had conducted survey research to determine the extent to which owners of working-class origins dominated the present and were 


\begin{tabular}{l|ll} 
& Concrete & Abstract \\
\hline Objective & Communists & "Old Guard" Elites \\
Subjective & "Self-Made Men" & Poor/ Dalits
\end{tabular}

Figure 1. Narrative genres in fieldwork, Tiruppur, 1996-98.

responsible for its spatial form. Having satisfied myself of these questions through a second trip, in which I was armed with the methods of survey research (see Chari, 2000; forthcoming), I returned to the difficult question of what work the ideology of toil played in the politics of work. This question lay embedded in the construction of the survey instrument I used during my second research trip. Indeed, initial qualitative research provided a window into the diversity of genres of narration and their divergent social-historic conditions of possibility.

The life-history interviews collected in my first research trip diverged into four genres of narration from broadly divergent social locations. I represented these four narrative forms in a decidedly crude diagram (Figure 1), derived from an ethnographer's toolbox provided by the teaching of Michael Burawoy at the University of California, Berkeley. The vertical axis represents the hermeneutics of participation in the act of narration, or the extent to which the speaker renders the narrative in personalised/ subjective or depersonalised/objective terms. The horizontal axis represents the particularity or generality of information provided in the narrative, ranging from the most concrete "data" to abstract "theory". Crude as this heuristic is, it reveals striking differences in the type of information I could access from different kinds of people, which would prove crucial to the kinds of claims I could make.
In making sense of this diagram, I found it most useful to view these narrative strategies against each other. Among the influential men in Tiruppur, the older generation of elites, the traditional mercantile and moneyed castes, narrated their histories in highly abstract ways, calling on scriptural authority as often as they could, and providing little detail of the course of events. In comparison, the communist party and union leaders spoke in similarly dispassionate ways but with a stringent materialism and attention to detail. I was given lists of material causes for anything and everything by the union leader Velusamy (interviews, 1 \& 12 December 1996), who narrated the history of the working class as a general drama driven by the inexorable dynamics of market deepening. Importantly, the working class enters this drama not as labourers in specific labour processes but as part of new habits of time-discipline, industrial labour and urban consumption of the products they laboured on. The banian or undershirt, the quintessential product of Tiruppur, was the working man's ideal work shirt, drawing the circuits of production and consumption directly into the making of the rational worker, shorn of his caste, if not gender, making mass consumer commodities that he might also consume.

On the other hand, narratives of self-made men, such as the quotations that launch this section, demonstrate both granular detail and, in contrast to both communists and elite owners, extremely subjective renditions of 
events. The attribution of personal success to the author's own effort, and the mingling of personal and regional accounts are striking in these narratives. I will argue that this is but the tip of the iceberg, as self-made men continue to enact their propensity to toil in mundane acts of work. In striking contrast, the narratives of poor people who have stayed poor are rendered in subjective terms, but without the same attention to detail. Instead, these subaltern narratives tend to replicate the verities of various elite narratives, or of invoking fate, bad luck or "bad time" as reasons for their lot in life. A particular event, early in my fieldwork, crystallised very different assumptions in these subaltern narratives. After an old man in the outskirts of Tiruppur had narrated fragmentary moments of pain in his life - interjected with statements like "they used to beat us" - he broke into tears and thanked me, as a fellow Tamilian, for coming all the way from America to bear witness to his difficult life. What surprised me as an ethnographer-in-training was that he had not in fact provided any precise details of these difficulties, but seemed to assume that I knew how to interpret his pain. I took this as an act of opening a shared space for empathy, which served to strengthen my resolve as a fieldworker. Another experience with subaltern narratives, however, would call this utopianism into doubt.

Narratives of Dalits, in particular the Madaris $^{3}$ in the environs of Tiruppur, proved to be hard, for me especially. Based in Tiruppur, I thought I was lucky to not be in a part of Tamilnad where I'd be found out as of the particular Brahmin sect with which my extended family affiliates. Indeed, I had become used to a kind of cosmopolitanism in Tiruppur that allowed me to proclaim no allegiance to caste, despite its historical and social privileges. Arriving in a Madari village one day to find myself surrounded by men who were loath to open up to me in any clear way, I was rightly put in place for assuming my intentions of solidarity would be easily resolved. "Tell him we're the Cakkilian, we're the Parayan, we're the Harijan", ${ }^{3}$ said one man to another in disgust. My conclusion was that these subalterns were under no illusions that the extraction of knowledge would mean anything to their material conditions, or that the grounds of "speaking-for" could change in the foreseeable future in ways that could alter my position as another elite parasite. Needless to say, my experience as a fieldworker was not always this difficult, and there were several individuals who broke out of the crude diagram of narrative genres I have sketched. What was striking was that the only consistent genre that provided me both detail and a sense of personal involvement, both crucial elements for my work of social scientific reconstruction of the dynamics I had sought to understand, were "self-made men". Therefore, it is not surprising that these individuals have been, for better or worse, the key actors in the story I could tell. The production of knowledge in the field sharply circumscribed the kinds of claims I could subsequently make.

Having reconciled myself to this, I sought a range of personal narratives that could allow me to triangulate the cultural historic and placebased conditions of possibility that frame Tiruppur's self-made men. I was lucky to befriend Arumugam, a non-Gounder worker in Tiruppur knitwear for many years before returning to his caste profession of washing and ironing clothes for private households. Arumugam's account (interview, 3 December 1997) provided me an initial counter-narrative of Gounder toil from someone who did not see it as a recipient, but as a non-Gounder observer who could see a particular set of shared relations that turned some people's toil into capital.

A: Owners gave all responsibility to the contractor. It's good profit for the owner. Nobody gets [benefits]. The owner says he has no relationship [to workers]. They kept workers temporary for ten years even... Actually, through support, that's how they became [owners]. If you are just within a 
company and are just a worker you cannot do it. Only if someone says in the bank that he knows the worker so put something down, only then can he rise up. Not from one's own toil. There was work for one to nine months. If there was [regular] work, there may have been a chance. You can't be a labourer and come to the front. If someone supports at the bank, one can... There's no casteism here. Any caste can know the work and do it.

\section{S: Then how did Gounders "rise"?}

A: Yes, they have inheritance. They can manage with inheritance and "background". They didn't just do it themselves. Either they have land, or means, or someone gives it to them. It didn't work for me so I said okay, I'll do my own work.

While stripping the illusion of "self-making" from Gounder class mobility, Arumugam indexes the centrality of an ideology of toil based on other things, like land and family background. Gounders would also sometimes let slip the importance of the State Bank of India's extension of state credit in the making of self-made men.

In the morning I'd go to the bank. In the afternoon I'd watch cutting. I could cut and iron, my two brothers could stitch and another brother could also cut. Since 1967 when we started, and at least until each of us got married, we'd all work from 6 a.m. to 12 p.m. daily. The reason for our development is bank support and our toil (L.M.K. Balu, interview, 26 February 1997).

An older elite interviewed in the early 1980s, before Tiruppur's great leap into the global market, betrays a kind of disbelief in the power of Gounder owners of small firms that produced only part of the labour process in linked chains of small concerns. Soundappa Chettiar (interview in Mandakini, 1983) was one of Tiruppur's great textile mill owners, who could not see subcontract units as viable.

[By 1972] a large number of small units appeared with a few knitting machines and began to sell knitted fabrics. These pseudo-manufacturers are mostly traders [who] get the yarn knitted from knitting units, have the fabric bleached at a bleaching unit and get it tailored from a tailoring unit according to their own standard. These pseudomanufacturers have no stake in business... [They are] not responsible for statutory obligations such as factory license, E.S.I., P.F. [Employers State Insurance, Provident Fund] and gratuity. The composite units represent the industry in the real sense.

As I pieced together the many ways in which Gounders of modest means did in fact call Soundappa Chettiar's bluff, taking over Tiruppur and transforming its integrated firms into decentralised networks run by a fraternity of small owners, I had still to make sense of all those who, in some sense, missed the boat. Despite the fact that these Gounders would indeed take over the town and make it over as India's premier knitwear export site, one cannot read the present back into the past. I had to make sense of the multiple failures that constituted the success of Gounder self-made men. I turned, therefore, to research three classes of failures: the aristocratic Kaniyalar Gounders who came from large landholding families; the older guard of knitwear owners of traditional mercantile capital origins; and fractions of India's big capital that have tried to make inroads into this boomtown.

The aristocratic Kaniyalar Gounders, large landholders who would never touch the plough, are now left in the lurch in their rural palaces. There were two major attempts by the older generation of these agrarian lords to enter the domestic knitwear industry with the large amounts of capital, semi-bonded labour 
and political influence they had ready at hand. Both ventures failed. In fact, their sons tried and failed in the era of exports. Victory Knitting was started in 1958 by "Kittu" Gounder, who now sits in his abandoned cotton gin on prime real estate near the river, with a then astronomical initial investment of Rs. 600,000 and about 30 stitching machines. This was a large unit, and it ran for ten years before grinding to a halt at a dead loss. Kittu Gounder (interview, 19 February 1998) said to me:

One has to live there, in the knitting factory. You have to be there. We are a type of family. We cannot go and sit personally. Our relatives are also equally important men. They cannot go and sit either.

His son Mahesh is a savvy young man who started a large unit called Kalinga Fabrics in the early 1990s with a Rs. 2 million (about US\$65,000 in mid-1993) investment, 20 local knitting machines and 30 stitching machines. The unit operated at a loss because processing remained uncontrollable, and Mahesh (interview, 19 February 1998) confessed, "in this trade the boss is the manager and he has to be on the shopfloor 18 hours a day".

Another major joint venture of these aristocratic Gounders involved relatives of a prominent ex-minister (Mandradiar, interview, 15 March 1997), who referred to himself as "the Pope of the Gounders" (the Pazhaikottai Pattakarar). K.M. Gounder's (interview, 24 December 1996) Vinayaka Knitting began in 1955 with 11 fabrication and eight stitching machines, and 45 workers. The company ran with managers until it stagnated in the mid1960s. His son Rajan, who attempted to revive the unit in the mid-1970s with an injection of Rs. 700,000 and undertake merchant production for the export market, also lost and left knitwear decisively in the late 1980s because he "was alone". Sitting near his posh hotel on the edge of his ancestral holdings on the outskirts of town, Rajan (interview, 1 March 1998) stressed that, for export, "one needs two to three partners or family involvement: one person in the company 24 hours, one person for finance and banking, and a third for buyers and marketing". His main problem was in management: "There's lots of loss and theft; the cutting master may not be cutting enough or sometimes they don't cut around holes, or piece-rate workers want speed and numbers and they need to be supervised". By the late 1990s, 70 to 80 per cent of new entrants, in Rajan's view, resolved this dilemma by teaming-up with a "working partner who works 24 hours, invests no capital and gets a salary plus a profit share". Until the late 1980s, however, aristocrats like him were entirely removed from appreciating the work of the average "toiling" Gounder. ${ }^{4}$

Similarly, the úr (town) Gounder, the traditional leader of the Gounders in town who is something of a mafioso, met a similar fate (Kandasamy, interview, 23 February 1998). All these aristocratic Gounders (including the "prince" of the Uttukuli Zamindar's family, D. Vanavarayar, interview, 22 February 1997) would simply admit to me that staying late at work, really mingling with their workers and supervising mundane activities was beneath their dignity, and none of their relatives would do these jobs either, because they were also of the same status. They also could not stomach the idea of dedicated production, that is, production for an established domestic or export firm; they felt this was too much like working for someone else. The agrarian elite failed because they just could not shake off their aristocratic relationship to work.

The second class of failures is that of the old guard of industrialists, traditional "business communities" who have been slow or in many cases unable to adapt to the supervision requirements of the new, decentralising production form. For four months, from October 1997 to March 1998, I lived at Delight Knitting, a kind of Dickensian factory-home owned by an Iyer Brahmin owner of this type. There were two 100-year-old buildings next to each other, with great halls 
and wooden pillars. The company was in one, with the Factory Acts posted in English and Tamil at the entrance, and only male labour inside - both features one would not see in export companies today. The owner sat at the centre of the second building, like a deity in the middle of a series of concentric rooms. Work was in one place; "business" in the other. The company has remained stagnant for a good 20 years; in fact, he'd say to me "this is Delight Knitting Limited: business is very limited". He never ventured next door to the shopfloor, and was disdainful of his ex-workers who have gone on to become exporters, wealthy beyond his dreams. He'd say, "they are only workers", with a sort of sneer, as he sat and watched train after train go by on the main line of South India. Work in this older factory has continued to be organised through a pyramid of patriarchal relations down from the manager to skilled male workers and young boy apprentices. Another old guard owner, a Muslim from the neighbourhood of Khadarpet, had a similarly stagnant business because he said he did not have the kinds of relatives and kinship networks that Gounders could muster to multiply their sister concerns (Kasim Bhai, interview, 21 November 1997). Industrial decentralisation increased the importance of direct control, and Gounders were simply best at it.

The third class of failures is of large industrial houses that have tried to make inroads into Tiruppur. I went to nearby Coimbatore city to find out why one of the great Naidu industrial families of South India had failed in its venture in Tiruppur knitwear. ${ }^{5}$ Sathyaraj, a scion of Coimbatore's textile mill elite, set up a knitting fabrication and manufacturing concern in the mid-1980s, when the government was encouraging exports. For several years, the concern broke even, but then it lost everything with one big failed export order to the United States in 1991. One set of reasons for this loss had to do with unfair, indeed illegal, business practices on the part of the buyer. The other major problem was mismanagement. Production control was deputised to a manager who gave out subcontracts to family members, but could not deliver the goods for an order that was far beyond their combined capacities. Sathyaraj (interview, 10 February 1998) faults himself: "unless you are involved, it is too risky to do business in Tiruppur". He explained that because product specifications vary so much in knitwear, as opposed to his familiar world of spinning and weaving, one has to rely a lot more on subontractors who have more "opportunities to cheat". Sathyaraj was also frustrated by the way in which dyeing units in Tiruppur take on multiple orders and then execute them in a seemingly random order. When I pressed him on how locals do it, he exclaimed:

Gounders are able to manage their own brother-in-laws [sic], brothers and so on. In Tiruppur, the whole family might be involved in the business. Here [in Coimbatore] it is not like that.

In the end, this industrial tycoon from only 50 $\mathrm{km}$ away found Tiruppur's work culture alien and unmanageable because of what he called "family supervision" over production networks. Seven years after closing shop, he is still trying to get payments from ex-suppliers in Tiruppur through legal means, as he will not take recourse in the local techniques of goondaism (gangster tactics), or of the threat of violence wielded by local "collection agencies". He said with a sigh, "Tiruppur people know how to get things done; we [Coimbatore Naidus] are soft, not violent people".

The secretary of the Tiruppur Exporters Association (TEA), Subramaniam (interview, 3 March 1998), a thoughtful man who worked for several years for the mill owners association in Coimbatore, reiterated similar views based on his comparative experience:

Knitwear export is a highly personalised business. North Indians like Fulchand or Arora who do business 
here, they are here. The owner must be at the spot. This is not mass production. In big factories you can have absentee management and control. Professional management has not succeeded here. It is because Tiruppur is full of small people who have become big, and they cannot get over the habit of direct control. They won't talk to subordinates, only equals. The boss will only talk to another boss. Big firms like Tata face barriers despite their advanced systems because their overheads are higher. The inherent advantages here are of a mobile workforce and highly segmented industry.

Subramaniam pins the advantages of direct control in Tiruppur's social division of labour as a consequence of, not despite, the informalised and fractured organisation of work. Moreover, he attributes the importance of direct control by the boss to his typically humble origins.

In another instance, a Gounder owner of modest origins narrated how a manager from one of the largest industrial houses from North India came to meet him to arrange to source garments from Tiruppur. When the whitecollar manager simply asked about how the Tiruppur owner would produce for him, he shouted, "Get out!" and pointed to the door, because he had felt the white-collar manager did not give him enough respect as a boss (Yellowbee Velusamy, interview, 20 November 1996). Another owner, Kamaraj (interview 23 February 1998), told me from his experience in Tiruppur that:

even today exporters go around to suppliers and say "enna máppilai" ("how are you, brother-in-law") and sweet talk the boss... but the big industrial houses send their man to look after different segments of production and he will only talk to the corresponding management... our fathers were on the production floor... that was ulaippu... not this sweet talking, this is P.R. ${ }^{6}$

A Tiruppur industrialist (Zintex Srinivasan, interview, 26 February 1998) makes a similar point in historical terms:

Hosiery needs personal involvement; otherwise there are a number of chances to take money out. In the low stages of development, local production was low profits and one had to watch workers. The first workers who became owners couldn't go into banking or government lobbying because of their low educational levels, but they knew how to work. Now exporters have higher profits and owners have a lot more duties. Now there aren't responsible financial practices or prompt delivery. Still, personal involvement is necessary because all the power is concentrated in the owner. If you give chances, your subordinates will go out and start their own companies, and they are treated as traitors.

Srinivasan distrusts the decentralisation of production for the increased opportunities it provides for poaching, and he sees "personal involvement" as key to rectifying this problem. He also suggests that Gounders from workingclass origins concentrated on control over the detailed division of labour while, through time, their sphere of control has extended over a broader set of activities involved in making garments, necessitating control across social labour. What is clear through these views on Tiruppur is that there is something particular about the activities of Gounder owners of working-class origins, having to do with their presence and active involvement in the organisation of production.

This swirl of interview information points directly to the labour process as it has been configured in particular ways by broader social 
relations. Certainly, the idea of workers aspiring to class mobility appears to be entirely counter-intuitive to the dynamics of capitalist development. My friend "Disco" Ravi, a cutting "master", persisted in the hope of starting a unit someday, despite being under no illusions as to the difficulties that workers face. The circulation of successful rags-toriches stories allows even workers who suffer the indignities of seasonal work to envision the faint possibility of class mobility. This is not to say they do not also mock the idea or realise, as I came to, how such opportunities are deeply exclusionary, as in the incident I have related about my friends twirling their imaginary moustaches like "big capitalists". One of these men, a Dalit Christian with the improbable name Dastan Bannatic Kings, did in fact start a processing unit in partnership with other workers the following year. I found workers' perceptions of opportunity lying in uneasy tension with their representations of pathetic working conditions and of a profound sense of insecurity. My worker friends at the tea stall were commenting on this tension in their sarcasm, on the one hand realising a basis for Tiruppur's rags-to-riches stories, while on the other hand replying, "It's not quite me". My friends knew that the ideology of self-made men operates extremely selectively, relying crucially on their misrecognition as workers who can certainly not all make the class leap.

The recollections of a non-Gounder worker provide a final perspective on Gounder toil and the class mobility it has allowed. Disco Ravi (interview, 13 July 1997) has been a cutting worker from the ages of 12 to 28 and is a staunch member of the Congress of Indian Trade Unions (CITU), the labour union of the Communist Party of India-Marxist. I asked him whether it is true that many workers think they will become owners. He responded, "That kind of thought is there; even I have it". I asked if he had friends who have gone from worker to owner. "Oh, many, there are many", he replied, adding, "owners to a certain extent: first they went on a cycle, then a scooter and now a [motor] bike - to that extent; some are even in the party". Ravi's optimism about becoming an owner was soon tempered by his views on those who had:

They only try to suppress other men. Suppose a Gounder boy goes to work they'll give him preference... he's "our boy," "mappilai's boy", "sister's boy", let him have his own section. Give him some extra. If I do it they'll say, "give the guy Rs.0.25"; for him they'll say "okay, give him Rs.0.50". I keep going down; his wage keeps going up. Most of the big company owners are Gounders. "We must look after our men": their only aim is to look after Gounders. Whether they're big or small, they support each other.

In concluding, I descend into the hidden abode of production, and into the ways in which I sought to use ethnographic observation of work practices to continue to make sense of the conditions that made space for Tiruppur's self-made men.

\section{THE CULTURAL PRAGMATICS OF TOIL}

As I spent time in Tiruppur's knitting factories, I became aware of the ways in which Gounder toil was not simply part of the narrative strategies of Tiruppur's inhabitants, particularly of Gounder self-made men. In this section, I want to argue that toil is enacted in the labour process as Gounder men of working-class origins work alongside their workers. I often found it difficult to spot the owner when I entered a knitting company, as he was immersed in the labours of producing garments. In turning to the "cultural pragmatics of toil", I argue that it is important to move beyond thinking of categories learnt through fieldwork solely in referential rather than also in indexical ways. In other words, it became important for me to understand toil in practice.

Brusquely put, linguistic anthropologists drawing from pragmatic and materialist 
traditions of semiotics, particularly from the philosopher C.S. Peirce's distinctions between icon, index and symbol, argue that while referential signs such as symbols name or describe in arbitrary ways defined by changeable conventions, non-referential signs can be linked to objects in much less arbitrary ways (see, for example, Lemon, 2000:25-27). The point is to be able to discern different types of non-arbitrariness in signification. Icons, for instance, work by resembling that which they represent, as statues resemble particular people. Indexical signs work by pointing towards the objects or relations through which they have been produced. In order for indexical signs to work, participants must implicitly understand their context of production and use. Here, as Lemon's (2000:25) discussion clarifies, context "is not limited to the 'real-time' here and now but can include knowledge about the past, about social hierarchies, or about cultural and generic associations". ${ }^{7}$ It is in this sense that one can speak of acts of Gounder toil in the division of labour, pointing towards specific structural and social historic relations that remake working people and places in specific ways. Indexical signs open up the practices through which toil recruits subjects in practice.

If toil "recruits" subjects, it does so differentially, making room for acts of misrecognition such as my moustache-twirling worker friends. In other words, self-made Gounder men can hinge their retrospective narratives of success on their toil, naturalising the sign as marking their difference, precisely because they are the privileged subjects whose specific historically constituted capacities are indexed in everyday acts at work. As an indexical sign, toil works specifically for Gounder men who implicitly relate to the context of its production and use, which is why I also refer to this sign as "Gounder toil". Today's flexible proletariat do not, for the most part, recognise themselves as ulaippalis or toilers in this respect. On the rare occa sions that non-Gounders stake claims to being able to turn their toil into capital, they know that toil is not quite their advantage, and yet some non-Gounder workers have used the structural openings in Tiruppur's industry to forge their routes of class mobility. Misrecognition is key to the dialectics of toil, as this sign hails all workers to realise the value of their labours, while valorising the specific labours of "selfmade" Gounder men. Toil seems to reference hard work, while, more importantly, it also indexes a specific agrarian history. Misrecognition means that others may see toil referentially, but for Gounders the propensity to toil materialises advantages made by structural opportunities, not degrees of effort. Precisely because toil recruits subjects selectively through its multifunctionality, it becomes the linguistic means for reworking social and spatial difference, hence remaking class and place in a particular geography of accumulation (see Eagleton, 1991:142-6). ${ }^{8}$

I have circuited through these insights from linguistic anthropologists in order to drive home the point I began with in posing my opening remarks about not taking language in ethnographic fieldwork at face value, or in only its referential aspects. Textual analysis alone misses what linguistic anthropologists call the cultural pragmatics of language. While working alongside their workers in stitching sections, Gounder owners could enact their propensity to "toil". In these daily acts of toil, as I argue more fully elsewhere (Chari, forthcoming), Gounder owners and their workplaces were being renovated through the effects of a specific, gendered agrarian history of work discipline. Moreover, by prising stitching sections as separate units of production out of formerly integrated firms, "toiling" Gounders made space to draw in and make "toiling" owners of their male kin and castefellows. As an exercise of both class power and Gounder masculinity, "toil" allowed Gounder men to link power over the labour process in stitching to power over social labour across networks of firms. Consequently, they remade themselves as a new class fraction, which I call the Gounder fraternity of small capital, while turning the 
entire town into a decentralised factory. Cases of loss - of the agrarian ancièn regime of Kaniyalar Gounders, of the older guard of industrialists, and of large non-local textile houses - can be seen as failures in part because they did not carry the shared cultural political economic advantages indexed by Gounder toil.

\section{CONCLUSION}

I have sought to demonstrate through fieldwork in South India, and through the methodological insights of Carolyn Steedman and linguistic anthropology, the importance of non-referential forms of signification to ethnography. What one says is often highly conditioned by genres of narration that then condition the types of stories one can tell. However, this is not cause for Marxist geography to forsake its crucial reliance on ethnographic methods. Indeed, what it means is that geographers must pay better attention to how things are said, and to the ways in which broader structural, cultural and social-historic relations are metonymically revived in practice. I have only begun in this article to suggest how subtle movements of affect and comportment accompany the production of knowledge, but I want to stress that this only means that social and cultural analysis must accompany each other rather than coming at the other's expense. Fieldwork in the postcolony might not be quite as doomed as those who remain dumbstruck by the problem of subaltern representation. Self-made men might be rare, but they point to the importance of attending to the changing cultural and material grounds of speaking-alongside the subaltern. The exclusionary nature of Gounder toil points to the importance of translating subaltern difference in order to further transform the many forms of political subordination through which subaltern marginalities persist.

\section{ACKNOWLEDGEMENTS}

I am grateful for generous funding for research from the Social Science Research Council's
International Pre-Dissertation Fellowship Program, the Fulbright-Hayes Doctoral Dissertation Research Award, the University of California Chancellor's Fellowship and a Postdoctoral Fellowship from the Michigan Society of Fellows. For insights herein, I am grateful to a host of people from Ann Arbor and Berkeley to Chennai and Tiruppur, including Michael Burawoy, Gillian Hart, Webb Keane, Alaina Lemon, Padmini Swaminathan, Michael Watts, Marina Welker and an extremely astute $S J T G$ reviewer; all shortcomings are mine alone. This paper was inspired by Carolyn Steedman's visit to the University of Michigan in September 2000, and was first presented, thanks to Tad Mutersbaugh, at the Association of American Geographers' Annual Meeting in New York City, March 2001.

\section{ENDNOTES}

1 Thanks go to Webb Keane for introducing me to Boas' 1887 essay, originally printed in Science, 9, 137-41.

2 An artefact of East India Company language, O.C. means free, with a hint of hoodwinking or making an angle - perquisites that officers could get "on company" account. It is now a common Tamil expression.

Terms used by various constituencies to describe subaltern groups outside the caste system. There are multiple genealogies to these terms; in practice (since the constitutional abolition of untouchability in postcolonial India), they refer to people treated as (or formerly) untouchable. In Coimbatore, Cakkilian is the specific and most derogatorily used term for the labouring groups in Gounder farming; Madari is the preferred affirmative term. Dalit, meaning the oppressed, is the politicised term used by activists representing the Harijan (the term coined by M.K. Gandhi).

4 Rajan claimed not to know the term Kaniyalar, which marked off his class of agrarian lords from the average Gounder peasant, but admitted that his families had recognised their mistake of being too aristocratic and are trying to become more "entrepreneurial".

The Naidus of Coimbatore city were large agriculturalists, many of whom made an opportune shift into the spinning mill industry when Indian capital took over the reins from British mills in the interwar period. Sathyaraj is a product of precisely this lineage 
and epitomises the industrialist who invests in public institutions. Coimbatore industrialists prize their public image; when I went to interview the patriarch of this industrial group, I was first presented his published biography.

6 On one of my visits to a far-flung processing unit, I witnessed a visit by a prominent owner, Dollar Ravi, who, when I said I was from Los Angeles, replied that when in those parts he only stays in Bel Air. When I asked why he could not send his quality control staff to check on progress in this remote unit, he laughed and pointed, with his cup of tea raised, to the printing owner: "If I don't come and sit across the table from my friend I'll never be sure my shirts are getting printed". $\mathrm{He}$ called this the "fieldwork" of an owner (Dollar Ravi, interview, 6 February 1998)

I am grateful to Alaina Lemon for clarifying the distinction in my work between people's renditions of their narratives through the language of ulaippu in interviews to me, and enactments of these narratives in particular contexts where the sign "ulaippu" works indexically, allowing past practices to interpellate the present. This connection between indexicality and interpellation has proven to be central to the logic of my argument, for which I am also grateful for discussions through the Reading Group on the "Materialist Semiotics of Value" organised by David Pedersen of the Anthropology Department under the auspices of the Doctoral Program in Anthropology and History and Center for the Study of Social Transformations, University of Michigan, 2000-1.

8 I am grateful to Marina Welker for asking me whether toil is in fact employed selectively by those Gounder men in whose narratives of success it is emplotted retrospectively, or whether these Gounders might use it indiscriminately while its selective operation may have more to do with misrecognition. Marina's perceptive remarks on what she calls the "pragmatics of invoking toil" have been very important to my larger point and helped me clarify that, indeed, toil operates indiscriminately in most socio-spatial domains with the exception of the "stitching section", which I maintain is the crucial place where workers and the owner-worker can share implicit associations at work (discussion at the "Agrarian Questions" Seminar, Anthropology and History Departments, University of Michigan, Ann Arbor, 17 April 2001)

\section{REFERENCES}

Boas F. (1966) 'The study of geography [1887]', in F. Boas, Race, Language and Culture,
New York: Free Press, 639-47.

Chari, S. (1998) 'The agrarian question and industrialization in Tiruppur, South India: A historical geography of the industrial present', in M. Goodman \& M. Watts (eds.), Globalising Food: Agrarian Questions and Global Restructuring, Routledge, 79-105.

Chari, S. (2000) 'The agrarian origins of the Knitwear Industrial Cluster in Tiruppur, India', World Development, 28(3), March.

Chari, S. (forthcoming) Fraternal Capitalism: Peasant Workers, Self-Made Men and Globalization in Provincial India, Stanford: Stanford University Press and New Delhi: Permanent Black.

Eagleton, T. (1991) Ideology: An Introduction, New York: Verso.

Lemon, A. (2000) Between Two Fires: Gypsy Performance and Romani Memory from Pushkin to Postsocialism, Durham: Duke University Press.

Spivak, G. (1988) 'Can the subaltern speak?', in C. Nelson \& L. Grossberg (eds.), Marxism and the Interpretation of Culture, Urbana: University of Illinois Press, 271-313.

Spivak, G. (2001) 'Moving Devi', Cultural Critique, 47, 120-63.

Steedman, C. (2000a.) 'The autobiographical injunction', paper presented to the Public Colloquium, Center for the Study of Social Transformation, University of Michigan, Ann Arbor, 20 September.

Steedman, C. (2000b.) 'Biographical space: The case of Eleanor Marx', paper prepared for the Faculty Symposium, Center for the Study of Social Transformation, University of Michigan, Ann Arbor, 21 September.

Williams, R. (1997) Marxism and Literature, Oxford: Oxford University Press. 